\title{
Characters in hypno teaching and neuroscience: an overview
}

\author{
Achmad Setya Roswendi ${ }^{1}$, Ahmad Khoiri ${ }^{\left.2^{*}\right)}$, Denok Sunarsi ${ }^{3}$ \\ ${ }^{1}$ STIKES Universitas Jenderal Achmad Yani Cimahi, Indonesia \\ ${ }^{2}$ Universitas Sains Al Quran Jawa Tengah di Wonosobo, Indonesia \\ ${ }^{3}$ Universitas Pamulang, Banten, Indonesia
}

\section{Article Info \\ Article history: \\ Received Jul 21st, 2020 \\ Revised Aug 20th, 2020 \\ Accepted Sep 19th, 2020}

\section{Keyword:}

Characters

Hypno teaching

Neuroscience

Systematic Review

Education

\begin{abstract}
Moral degradation as an indicator of the weak character of students who represent the character of the nation is increasingly concerning, the study aims to identify characters through Hypno teaching and neuroscience studies. Literature research with a systematic review through previous research in the years 2010-2019. The results showed that the contribution of Hypno teaching is very important in realizing student character through the cognitive development of children's brains. Student characters are motivation, selfefficacy, empathy, and sympathy for others. the contribution of the research is great hope for the life of the nation in the future in realizing a golden generation of character.
\end{abstract}

(C) 2020 The Authors. Published by Indonesian Institute for Counseling,

Education and Therapy (IICET). This is an open access article under the CC BY license (https://creativecommons.org/licenses/by/4.0/)

\section{Corresponding Author:}

Ahmad Khoiri,

Universitas Sains Al Quran Jawa Tengah di Wonosobo

Email: akhoiri@unsiq.ac.id.

\section{Introduction}

Education is the foundation of the hope of a nation to exist amidst the struggles of international community life. Indicators of the success of an educational process are detected from the quality of Human Resources. Quality Human Resources are born from quality educational institutions. The quality of educational institutions will, of course, be influenced by the quality of a learning process, because the learning process in the opinion of the writer is the spirit of an educational institution. However "sanctified" a policy, when the policy is not able to be interpreted properly in the learning process, the policy will be "barren". Call it a policy about the curriculum, the fact that occurs is a series of changes in the education curriculum in Indonesia, so far it has not shown significant results. Related to this problem, then in this case the teacher is the main actor in the design and quality of a quality educational institution, also several other factors. Without the active involvement of the teacher, education is empty of material, essence, and substance. As sophisticated as any curriculum, vision, and mission, and financial strength, as long as the teacher is passive and stagnant, the quality of educational institutions will decline sharply, and vice versa. Environmental factors and social competence also greatly influence student character (Cheung \& Lee, 2010; Pane \& Patriana, 2016).

Teachers as actors who are directly involved in the true learning process can create innovative products that emerge from creativity and high reasoning power. Creativity according to Balnadi Sutadipura as stated by Jamal Ma'mur Asmani becomes an important element for a teacher. Creativity is the ability to discover something new by using imagination, fantasy, or imagination. In the learning process, the failure of a method is when the method is a place to rest for too long so that someone can not be independent and depend on the method. If teachers and teachers understand how to communicate with students' subconscious, it will certainly help in the teaching and learning process. One of the communication methods that is used and is quite popular today is hypnosis techniques. Hypnosis is the art of communication to influence someone by changing their 
level of consciousness. Neuroscience plays an important role in students' cognitive (Carew \& Magsamen, 2010). Hypnosis is not only useful for overcoming problems involving physical or psychological conditions but can also be used to optimize the learning process. Hypnosis in the learning process is known as Hypno teaching, a learning method that is done by hypnotizing students through the suggestions given by the hypnotist (Masdudi, 2018; Rusdi, 2015). So it is very important to be studied in the world of education as a gold generation character builder in learning success (Mei-Ju et al., 2014; Rokhman et al., 2014). Problems in empowering students' thinking skills through creativity, problem-solving skills, critical thinking can be studied through neuroscience with the Hypno teaching strategy. the interest of students is not just the completeness of learning outcomes, but how to build student character with good thinking skills.

\section{Method}

The library research method with a systematic review approach reveals the study of hypnotherapy and neuroscience in realizing student character through educational practice. Collecting data using the method of documentation from various journal sources that can be accounted for in the years 2010-2019. Systematic review is used based on Miles and Huberman's analysis techniques by identifying Hypno teaching and neuroscience literature data, then reducing the required data based on the research objectives, namely identifying student character through Hypno teaching and neuroscience, the final step is drawing conclusions based on the findings of literature that is critically studied (Sugiyono, 2011).

\section{Results and Discussion}

The results of the research are presented based on the identification of data related to the Hypno teaching method which must have several elements in a teacher through discussion of elements, implementation in ideal education, the impact of learning, and the Hypno teaching model (Rusdi, 2015). Furthermore, neuroscience studies as a basis for students' thinking abilities on the parts of the nervous system that contribute to it (Carew \& Magsamen, 2010).

\section{Hypnoteaching Elements \\ Teacher's appearance}

The teacher should be well-dressed, a good appearance will give birth to high confidence and has a strong appeal for students (Zuhri Dj \& Sukarnianti, 2015). Usually, other people see someone from their outward appearance because appearance is a reflection of the person's personality. Of course, as a good teacher, the teacher will feel inappropriate when teaching class using a T-shirt, flip flops, gloves, and a hat. Instead, he will teach with neat clothes, shiny shoes, and wear perfume. Of course the second appearance will make the teacher more confident and students will more trust the teacher's ability. Teacher's appearance as a figure that is admired by students through an attractive appearance.

\section{Empathic attitude}

As an educator, the teacher is not just a teacher. A teacher must have empathy and sympathy for students. Teachers who have sympathy for their students will try hard to help and are determined to advance them. When it is found that many students are troubled, like to throw tantrums at school, like to disturb friends, and various other destructive actions, teachers who empathize will not simply give the title "bad student" to the student concerned. The teacher will first investigate the reasons students do these things by exploring and gathering various available information. Empathic safe and comfortable feelings greatly affect the character of students (Asteria et al., 2017) and high curiosity. In contrast to teachers who do not have sympathy and empathy for students. This teacher is so easily provoked his emotions if there are words of students who are not pleased in his heart. The student in question will be claimed as a naughty, stupid, problematic student, and usually just throwing tantrums at school. In fact, he also thinks that students like that should be expelled from the School.

\section{Sympathy}

If the teacher has sympathy for his students, surely his students will also sympathize with him. For example, the teacher treats students well even though the student is very naughty, so automatically he will respect the teacher who also respects him. Students will try to understand and obey what the teacher says because the teacher also understands himself. Attention will also affect changes in student attitudes (Was et al., 2016). 


\section{Use of language}

Language speech symbolizes the contents of the heart. In other words, what comes out of the verbal symbolizes the state of the heart and feelings. A good teacher should have good vocabulary and language and are pleasant to the ear, able to hold back emotions, are not easily provoked by anger, do not like to insult, or corner students with various words that should not come out of their tongues. Teachers who are able to maintain their verbal well, surely students will not dare to say sentences that hurt him. Hypnoteaching is presenting subject matter using subconscious languages (Rusdi, 2015).

\section{Implementation of Hypnoteaching in Ideal Education Demonstrator}

One element of hypnosis in the learning process is visualization or self-expression. All limbs are moved when needed. When the teacher explains, efforts are made to use gestures so that what he conveys is more impressive. But to implement this, the teacher must master the material first. Teachers who do not master the material will usually teach students in a boring way. The conscious mind and the subconscious mind are interdependent with each other (Salami, 2017). Learning will also be more effective (Anwar, 2017).

\section{Motivate students with stories or stories}

One of the successes of hypnoteaching is to use story and story techniques. When teachers see students experiencing problems, lacking motivation to learn, and various life problems, the teacher can advise and guide them through the stories of successful people who are related to student problems. And can improve reading skills (Lismalinda, 2019) and writing skills (Amaluddin, 2019).

\section{Mastering the minds of students}

If the teacher wants to master the minds of students, then the teacher must first master the hearts of students. The teacher must be able to understand how the students are doing. If the student has a problem, the teacher will try to help solve the problem. That way, the teacher will be able to master the hearts of students. Furthermore, the teacher gives encouragement and motivation to students. Little by little, our students' minds will be easily mastered, making it easier for us in the learning process. Positive student responses to the use of hypnoteaching models greatly affect learning outcomes (Puspitasari, 2018; Taufik \& Suryanti, 2018).

\section{Hypnoteaching function}

The function of this hypnoteaching learning method is: Eliminating the mental blocks of students, Motivating students to be more happy to learn, To facilitate mastering the minds of students during the learning process, so that the learning process will run smoothly, Fostering confidence in the participants students. As well as developing inclusive education for teachers and education practitioners (Sholihah, 2020), student communication skills can also be explored through hypnoteaching (Banu \& Nim, 2016). Information entering through the five senses is not directly absorbed by one's subconscious mind, but requires an analytical power of the conscious mind called the critical area. This critical area is needed in daily life as a filter of information to select things that are harmful and contradicting oneself. To overcome the critical area that is too active in a person, hypnosis is needed to deactivate the critical area, so that the information obtained by a person can be absorbed easily and stored in one's subconscious mind so that it can solve the problem in learning overcome learning disorders (Bali \& Masulah, 2019).

\section{Intention and Motivation in Yourself}

In implementing this method, a teacher must instill a strong intention, because this intention will bring high motivation and strong commitment (Hanifah et al., 2019; Kusuma, 2019; Sholekhudin, 2019). Pacing is to equate position, body movement always up to date knowledge related to the theme of the discussion Leading means to lead or direct something. This process is carried out after pacing. learning, the teacher must combine peacing and leading. The combination of these two techniques will create a conducive and effective atmosphere in learning. Use positive words, The next supporting step is to use positive language or words. Language greatly influences children's attitudes (Lismalinda, 2019), student motivation (Jayawardana \& Djukri, 2015; Khoiri et al., 2017). Give praise, is a reward for increasing one's self-esteem. No matter how small the form of achievement, still give praise. Including when he managed to make positive changes to himself, although it may still be below the standard of his friends, keep giving praise. With praise, someone will be motivated to do more than before. Learning messages can be conveyed through hypnoteaching.

\section{Hypnoteaching Modeling}

Modeling is the process of modeling with behavior. you can direct them as you wish, with positive sentences (Ismuzaroh, 2013), then it is also necessary to trust (trust) students in you established by your. So that you always become a trusted figure. Furthermore, a teacher must have broad insight when applying the hypnoteaching method to take the following steps: (Hakim \& Hariawan, 2017). 


\author{
All students are welcome to sit relaxed, \\ Clear your mind for a moment, \\ Inhale deeply through your nose, then exhale through your mouth \\ Do it repeatedly with regular breathing \\ Give suggestions on each breath so that the body feels relaxed \\ Do it continuously and repeatedly \\ Note the position of the head of all suyet. \\ For those who have fallen asleep, will appear downcast or neck is unable to withstand the weight of the head \\ Furthermore, give positive suggestions, such as focusing on the mind, sensitive to hearing, fresh brain and mind, and \\ comfort to the whole body \\ If it is enough, wake up the suyet gradually by doing count 1-10, then at count 10, all the ingredients will be realized in \\ a fit and healthy condition.
}

Hypnosis in learning is actually needed to stem students' critical area activities. When students' critical area activities are at a significant level, the information will be more difficult to receive and record in long-term memory (the subconscious). In this condition, students will reject information that is contrary to their wishes. For example, when students do not like one of the subject matters, of course, it will be difficult for them to accept the information conveyed by the teacher. This happens because in this condition the students' critical area activities are quite high. Thus, a teacher must be able to penetrate the CA through hypnoteaching methods. Andri Hakim revealed that to be able to penetrate CA, a teacher must understand several things in the hypnosis process including 1) Relaxation; the learning process must start with a pleasant atmosphere that can relax students, this is necessary to rest CA activities.

This relaxation can be created by paying attention to the atmosphere of the class, the teacher's appearance and opening sentences that can build student motivation; (Sri Imawati, 2018), 2) Mind Focus \& Alpha State; hypnosis in learning works at the alpha wave level, which conditions students to enter a hypnotic state (hypnosis state). In this condition students are expected to more easily record information into long-term memory; 3) Subconscious communication; communication is sometimes less effective and efficient. This is due to the absence of subconscious communication that supports the occurrence of a "two-way communication heart to heart" or two-way communication from heart to heart ". (Qomario, 2018).

Thus it is needed several things to build subconscious communication including a) inform the things that will be conveyed to students; $b$ ) the teacher must pay attention to the manner of delivery and the way of saying the information; c) conducive conditions or situations. In the learning process, a teacher can make this method as an alternative to being able to create an atmosphere of effective and enjoyable learning by bringing students into a relaxed atmosphere by changing the waves of students' minds into the subconscious. Thus the learning process can take place in a conducive atmosphere and foster student creativity.

In the hypnoteaching method, the teacher acts as a hypnotist, suyet case. Suyet is the name of a hypnotized person. The teacher as a hypnotist does not need to put his students to sleep when giving suggestions in the learning process. Teachers in hypnoteaching practice simply use persuasive language as a communication tool that can suggest students effectively. The language used by the teacher must be the language understood by students because it is very unlikely that hypnosis works effectively while suyet does not understand the language used by hypnosis.

When entering a class, the teacher is advised not to immediately give an opening greeting or give a lesson when the students are not ready to learn and the class is not conducive. The teacher simply sits sweetly in the chair without having to rebuke, advise, or get angry. After that, the teacher simply stared at each student who was still rowdy by using psychological strength in him. Take a deep breath, hold for a moment in the chest, and release slowly. Then watch the students' reactions. Repeat the activity over and over until your mind, heart, and feelings are truly calm, peaceful, and comfortable. After that, the teacher will be more relaxed, relaxed, and looks more patient than before. That's when students will stop rowdy and the class becomes more conducive and controlled. Students who are already sitting quietly and are ready to accept lessons automatically will reprimand and warn their friends who are still busy, sleepy or lying down. Without having to be emotional, the teacher directs the attention and concentration of students at one focus point, namely on the language of communication should be.

The teacher includes suggestions for making agreements with students. For example, "Teacher will only deliver the subject matter if the class is quiet." In the language of hypnosis, there is the term one wave. That is when we want a calm and controlled class before we have to calm down and control ourselves in facing anything. If we are emotional and angry when we see classroom noise, students will actually do the same 
thing, which is noisy, crowded, telling stories by themselves, daydreaming, drowsiness, lying down, and joking in front of us. If class conditions and student behavior can be mastered well, then students can obey whatever the teacher's directions.

When students are ready to accept positive suggestions and are ready to accept any program that will be put by the teacher into his subconscious brain, then the time has come for the teacher to give any positive program that must be done by students in their lives. These positive impressions are expressions that all students are bright and smart children, national exams are easy to do, English lessons, Mathematics, and other subjects are not difficult subjects, or students are told to choose grades in the form they want from a number of eyes lesson.

Hypnoteaching is not enough to only be done once or twice, but it must be done repeatedly by continuously repeating suggestion sentences. In this case, the teacher's expertise in using the hypnoteaching method will depend on the extent to which the teacher uses, practices, applies, and practices this knowledge in the learning process. This learning method emphasizes more on the ability of the subconscious brain than the conscious brain of students. The purpose of this learning method is actually opening or activating the subconscious mind. This is done because the subconscious mind is where the success or failure of a person. The subconscious mind plays a role of $88 \%$, while the conscious mind plays only $12 \%$.

The process of hypnosis to the subconscious will be very effective if the person who makes the suggestion is someone who has influence or is respected by suyet. Usually, teachers who have influence, are respected and are respected by students not because of their excitement, but because of the attitudes, traits, abilities, and personality of the teacher itself. If students are affected by the teacher's charisma, then the teacher really becomes a figure that can be trusted and followed. All words and advice that is very suggestive will be easily accepted by the students' subconscious minds. Hypnoselling is a hypnosis technique that is done indirectly by using communication. The main focus or focus is the elegant use of communication. The purpose of this communication is to use principles in accordance with the communication of the human subconscious mind.

\section{Neuroselling: Brain-Friendly Sales Strategies}

Explanation of the human brain in the human brain hypnosis method (Fadilah, 2018) can be identified that our behavior is controlled by our brain. The brain is the central nervous system that controls our decisions consciously or not. So, understanding how our brains work benefits us when we want to influence others. In sales, for example, understanding how the brain works will make it easier for us to reduce the prospect's resistance to the message we convey. This model is quite old and invites pros and cons, however, this model makes it easy for us to understand how the brain works in general. According to MacLean, based on its evolution, our brain is divided into three major parts.

\section{Brainstem and Cerebellum}

The reptilian brain is the oldest part of the brain in the human brain. Not only humans, reptiles (snakes, crocodiles, lizards, etc.) also have this kind of brain. The basic function of the brain is for survival. So, there are only two responses from the reptilian brain: fight or flight - face or run. This brain will light up when it faces a 'threat.' Whether the threat is real, or just based on estimates. Whatever the threat, this brain will light up and humans (or reptiles) will change to alert mode. When in alert mode, we become more selective in receiving information. Not only selective but even resistant to information. We will respond to this information in two ways: fight or flight. Fight means that we will reject and fight all the information that comes in, we are nagging, we are looking for evidence against that information. While flight means we run away, ignoring incoming information, ignoring it. Just imagine, when your prospects are in this mode, what will happen? Can you submit sales information when prospects are in this mode? I'm sure not. So, our job as sellers is to calm the reptilian brain.

\section{Limbic System}

The limbic system is the typical brain of mammals. All animals that give birth and breastfeed have this kind of brain. The limbic system is related to information processing, memory, and emotions. In this limbic system, there are three important components: the thalamus, the amygdala, and the hippocampus. Thalamus is a kind of system of receiving information from the senses (especially the eyes and ears). It should 'the information received by the thalamus is channeled to the neocortex so that information can be processed rationally by our brain. However, the amygdala often does piracy. When the information received by the eye and ear is considered 'threatening', the amygdala immediately reacts and hijacks information that should be distributed to the neocortex (amygdala hijack). The effect, we act irrationally. Not surprisingly, someone can be deceived because of their greed, because their behavior is hijacked by the amygdala. Not surprisingly, someone can buy things that are not needed just because of the desire for a moment. From this we can conclude, emotions play 
a very important role in the formation of behavior. This includes sales at the time of sale. So, when selling something touch their emotions, make them feel comfortable with us. Make them like our story. This will make it easier for them to buy from us.

\section{Neocortex}

The neocortex is the most modern brain functioning in developing creative, logical, and linguistic abilities. This brain makes humans have a culture and diversity of languages. The brain is what makes humans able to learn and create. At the front of the neocortex, there is a section called Pre Frontal Cortex (PFC) whose function is closely related to decision making, willpower, and the ability to distinguish good and bad. PFC is a kind of CEO of the brain. This is what distinguishes humans from animals. The neocortex gives humans the ability to choose freedom. The neocortex enables us to imagine the future and choose the most appropriate decision to make it happen. How is the application in sales? Invite them to imagine the future they want, and how your product can help them make it happen. So, we can conclude simply, so that our sales information is more easily accepted by them: make them feel safe, make them like us (and our products) and then show how our products help realize the future they want. Neuroscience learning becomes mainstream in developing characters (Erniati, 2015). The relationship between learning and neuroscience is ideal and successful (Pincham et al., 2014; Rato et al., 2011)

\section{Conclusion}

The contribution of hypnoteaching in learning strongly supports the character of the golden generation, student psychology is trained through hypnotic therapy in the subconscious. Motivation, self-regulation, sympathetic, empathy, and suggestions of students who influence learning outcomes. Disorder in learning is easily overcome when the subconscious is working on their respective functions. Neuroscience is able to explain with brain system therapy working on the neocortex that helps in growing the learning skills needed in the modern age.

\section{References}

Amaluddin. (2019). Pengaruh Metode Pembelajaran Hypnoteaching Terhadap Kemampuan Menulis Pantun Oleh Siswa Kelas XI Smk. Jurnal Pendidikan Bahasa Dan Sastra Indonesia, 4(1), 275-279.

Anwar, M. (2017). Menciptakan Pembelajaran Efektif melalui Hypnoteaching. Ekspose, 16, 469-480.

Asteria, P. V., Surabaya, U. N., Rohmah, S. K., Surabaya, U. N., Renhoran, F. Z., \& Surabaya, U. N. (2017). Penerapan Metode Hypnoteaching. Jurnal Pendidikan (Teori Dan Praktik), 2(2), 150-155.

Bali, M. M. E. I., \& Masulah, I. (2019). Hypnoteachingg: Solusi Siswa Learning Disorder. At-Turats, $13(1), 89$. https://doi.org/10.24260/at-turats.v13i1.1188

Banu, R., \& Nim, A. (2016). Penerapan Metode Hypnoteaching Dalam Upaya Peningkatan Kemampuan Komunikasi Matematik Siswa. Jurnal Matematika Ilmiah, 2(2), 95-99.

Carew, T. J., \& Magsamen, S. H. (2010). Neuroscience and Education: An Ideal Partnership for Producing Evidence-Based Solutions to Guide 21st Century Learning. Neuron, 67(5), 685-688. https://doi.org/10.1016/j.neuron.2010.08.028

Cheung, C. kiu, \& Lee, T. yan. (2010). Improving social competence through character education. Evaluation and Program Planning, 33(3), 255-263. https://doi.org/10.1016/j.evalprogplan.2009.08.006

Erniati. (2015). Pembelajaran Neurosains Dalam Pembentukan Karakter Peserta Didik Pada Pondok Pesantren. Hunafa: Jurnal Studia Islamika, Vol. 12, N.

Fadilah, M. (2018). Ekplanasi Ilmiah Metode Hipnotis terhadap Otak Manusia. Jurnal Filsafat Indonesia, 1(1), 8. https://doi.org/10.23887/jfi.v1i1.13969

Hakim, L., \& Hariawan, R. (2017). Mengelola Pembelajaran dengan Metode Hypnoteaching. Jurnal Kependidikan, $16(1)$

$150-162$. http://ojs.ikipmataram.ac.id/index.php/jurnalkependidikan/article/view/471/437

Hanifah, A. N., Sa'adah, N., \& Sasongko, A. D. (2019). Hubungan Kemampuan Penalaran Matematis dan Motivasi Belajar Siswa SMK Melalui Model Pembelajaran Hypnoteaching. Teori Dan Riset Matematika, 4(September), 121-130.

Ismuzaroh, S. (2013). Penerapan hipnoteaching melalui neuro-linguistic programmingdalam pembelajaran kimia. Jurnal Pendidikan IPA Indonesia, 2(2), 178-182. https://doi.org/10.15294/jpii.v2i2.2720

Jayawardana, H. B. A., \& Djukri, D. (2015). Pengembangan Model Pembelajaran Hypnoteaching Untuk Meningkatkan Motivasi Dan Hasil Belajar Biologi Siswa Sma/Ma. Jurnal Inovasi Pendidikan IPA, 1(2), 167. https://doi.org/10.21831/jipi.v1i2.7502 
Khoiri, A., Agussuryani, Q., \& Hartini, P. (2017). Penumbuhan Karakter Islami melalui Pembelajaran Fisika Berbasis Integrasi Sains-Islam. Tadris: Jurnal Keguruan Dan Ilmu Tarbiyah, 2(1), 19. https://doi.org/10.24042/tadris.v2i1.1735

Kusuma, D. A. (2019). Penerapan Ethnomathematics dan Hypnoteaching pada Mata Kuliah Matematika Kimia. JNPM (Jurnal Nasional Pendidikan Matematika), 165. https://doi.org/10.33603/jnpm.v3i2.2279

Lismalinda, M. (2019). The Influence of Hypnoteaching Method on students Reading Motivation and Achievment in Secondary School. Indonesian Journal of English Language Teaching and Applied Linguistics, $4(1), 39915587$.

Masdudi. (2018). Implementasi Teknik Hypnoteaching dalam Pendidikan Anak. Awlady:Jurnal Pendidikan Anak, 4(2), 20-45.

Mei-Ju, C., Chen-Hsin, Y., \& Pin-Chen, H. (2014). The Beauty of Character Education on Preschool Children's Parent-child Relationship. Procedia - Social and Behavioral Sciences, 143, 527-533. https://doi.org/10.1016/j.sbspro.2014.07.431

Pane, M. M., \& Patriana, R. (2016). The Significance of Environmental Contents in Character Education for Quality of Life. Procedia - Social and Behavioral Sciences, 222, $244-252$. https://doi.org/10.1016/j.sbspro.2016.05.153

Pincham, H. L., Matejko, A. A., Obersteiner, A., Killikelly, C., Abrahao, K. P., Benavides-Varela, S., Gabriel, F. C., Rato, J. R., \& Vuillier, L. (2014). Forging a new path for Educational Neuroscience: An international young-researcher perspective on combining neuroscience and educational practices. Trends in Neuroscience and Education, 3(1), 28-31. https://doi.org/10.1016/j.tine.2014.02.002

Puspitasari, W. D. (2018). Implementasi Metode Hypnoteaching Untuk Meningkatkan Hasil Belajar Siswa Sekolah Dasar. Jurnal Cakrawala Pendas, 4(1). https://doi.org/10.31949/jcp.v4i1.715

Qomario. (2018). Pengaruh Hypnoteaching Dalam Contextual Teaching. IImiah Kependidikan, 9.

Rato, J. R., Abreu, A. M., \& Castro-Caldas, A. (2011). Achieving a successful relationship between Neuroscience and Education: The views of Portuguese teachers. Procedia - Social and Behavioral Sciences, 29, 879-884. https://doi.org/10.1016/j.sbspro.2011.11.317

Rokhman, F., Hum, M., Syaifudin, A., \& Yuliati. (2014). Character Education for Golden Generation 2045 (National Character Building for Indonesian Golden Years). Procedia - Social and Behavioral Sciences, 141, 1161-1165. https://doi.org/10.1016/j.sbspro.2014.05.197

Roswendi, A. S., \& Sunarsi, D. (2020). Dinamika dan Perkembangan Hypnotherapy Dalam Perspektif Interdisipliner. Cilegon: Runzune Sapta Konsultan

Rusdi, fitria istiqoma dan A. (2015). Pengaruh Penerapan Mmetode Hypnoteaching terhadap Motivasi Belajar. 2(September), 83-90.

Salami. (2017). Hypnotic Teacher Dan Hypnoteaching. III(1), 34-44.

Sholekhudin, M. dan M. (2019). Pengaruh Metode Hypnoteaching Terhadap Motivasi Belajar Siswa Asrama Al-Falah Pondok Pesantren Darul Ulum Peterongan Jombang. Sumbula : Volume 4, Nomor 1.

Sholihah, W. M. (2020). Method And Model For Forming Teachers ' Readiness In Inclusion Education Practices. 07(01).

Sobarna, A., Hambali, S., Sutiswo, S., \& Sunarsi, D. (2020). The influence learning used ABC run exercise on the sprint capabilities. Jurnal Konseling dan Pendidikan, 8(2), 67-71.

Sri Imawati, P. K. W. (2018). Pengaruh Hypnoteaching Terhadap Motivasi Belajar Mahasiswa. Prosiding: Seminar Nasional Pendidikan Era Revolusi, 43-50.

Sugiyono. (2011). Metodologi Penelitian Kuantitatif, Kualitatif dan R\&D. In Alpabeta, Bandung. Alfabeta.

Sunarsi, D. (2018). Pengembangan Sumber Daya Manusia Strategik \& Karakterisrik Sistem Pendukungnya : Sebuah Tinjauan. Jurnal Ilmiah MEA (Manajemen, Ekonomi, \& Akuntansi), 2(3), 178 - 194.

Taufik, A., \& Suryanti, S. (2018). Efektivitas Penerapan Metode Pembelajaran Hypnoteaching Terhadap Hasil Belajar Matematika. HISTOGRAM: Jurnal Pendidikan Matematika, 2(2), 183. https://doi.org/10.31100/histogram.v2i2.206

Was, C. A., Woltz, D. J., \& Drew, C. (2016). Evaluating character education programs and missing the target: A critique of existing research. Educational Research Review, 1(2), 148-156. https://doi.org/10.1016/j.edurev.2006.08.001

Zuhri Dj, M., \& Sukarnianti, S. (2015). Using Hypnoteaching Strategy to Improve Students' Writing Ability. Dinamika Ilmu, 15(2), 185. https://doi.org/10.21093/di.v15i2.101 